\title{
Administrative Control and Evaluation
}

\author{
Dr. S. B. M. Marume ${ }^{1}$, R. R. Jubenkanda ${ }^{2}$ C. W. Namusi ${ }^{3}$ \\ ${ }^{1}$ BA, Hons BA, MA, MAdmin, MSoc Sc, PhD, Faculty of Commerce and Law, Zimbabwe Open University \\ ${ }^{2}$ BSc (Hons), MSc. Econ, MSc, DPhil (Candidate), Faculty of Commerce and Law, Zimbabwe Open University \\ ${ }^{3}$ BAdmin (Hons), MPA, Faculty of Commerce and Law, Zimbabwe Open University
}

\begin{abstract}
When all the administrative functions have run their course, the logical thing is that they must be controlled and evaluated in order to ensure that all operations were being undertaken according to plan and that policy results have been achieved as intended. This is the area of administrative control and evaluation.
\end{abstract}

Keywords: control evaluation monitoring results policy and administration

\section{Introduction to the Study of Control and Evaluation}

Those who are skilled in public administration scientists will realize that after planning has been done, and structure provided to facilitate the achievement of the objectives formulated during the planning stage and the leading function performed; the organizational arrangements, and all resources allocated to be used to Implement Aims and Policy (IES), and predetermined objectives have not necessarily been attained. Poor accomplishment of any of the administrative functions increases the necessity of making some appropriate adjustments, either in the means or resources used to attain the policy objectives or in the objectives themselves. (S. B. M. Marume: 1988). The processes which enable the monitoring of the activities and the assessing of the results are called control and evaluation respectively.

According to Professor S. P. Robbins (1980: 376), the concepts control and evaluation are defined as the final links in the functional chain of public administration. It is necessary to check activities in the public administration process, and one of the interrelated processes is the process of control which is to check activities to ensure that they are progressing as planned, and, where there are significant deviations, in undertaking these activities, to take the necessary and appropriate corrective action (Marume 1988 and Professor J. J. N. Cloete, 1985).

\section{Administrative Control and Evaluation}

Learning objectives

To be able to:

1. Define and explain key terms and concepts:

- Control

- Measuring

- Personal observation

- Comparing

- Public accountability

- Written reports

- Correcting
- Political control measures

- Statistical records

2. Define and describe terms and concepts:

- Evaluation

- Evaluation methodology

- Evaluation Research

- Roles played by evaluators

- Research typology

3. Appreciate the significance of control and evaluation in practical public administration.

Evaluation process

\section{Definitions of the Concepts Control and Evaluation}

These two concepts are examined as follows

\section{Control}

According to Robbins (1980:376, Cloete 1985, and Marume (1988), control may be defined as the process of monitoring activities of public officials in implementing policy decisions, programmes and plans in order to determine whether individual units and the institution itself are obtaining and utilizing their resources (money, personnel, material, time and so on) efficiently and effectively to accomplish their objectives, and, where this is not being achieved, taking corrective action. To adjust to changing conditions, and to compensate for previous errors, public administrators and their subordinates appraise previous and current organizational activities. They may then undertake actions, not only to correct actual deviations, but also to prevent deviations before they occur.

\section{Evaluation}

According to Professor Edward Suchman (1967:31-32), the concept evaluation may be viewed as the determination of actual practical results achieved by a specific policy designed to accomplish some valued goal 


\section{International Journal of Science and Research (IJSR) \\ ISSN (Online): 2319-7064}

Index Copernicus Value (2013): 6.14 | Impact Factor (2014): 5.611

or objective. However, the many evaluation typologies tend to evolve themselves into impact, relative effectiveness, and project performance. And the methods which are used to measure programme outcomes, depend partly on the type of evaluation intended and partly on the available resources which include, amongst other things, time, personnel financial resources, experience and expertise (Marume 1988).

Impact evaluation: seeks to measure the extent to which a programme has met its set legislative objectives. Relative effectiveness evaluation is intended to address the range of programme strategies, techniques, and processes available for achieving the legislative aims and objectives.

Programme evaluation seeks to measure the performance of project operations.

\section{Brief Critical Review of the Definitions of Control and Evaluation}

On the basis of broader knowledge basis, knowledge, wider experience of public administration, and intimate knowledge of the extremely rational and practical works of world renowned public administration luminaries in the names of Professor J. J. N. Cloete $(1967,71,77,81,85$ and 1994), strongly and hugely supported by public administration such as B. J Roux (1970 and 71); D. E. S Fourie (1970-77); P. S Botes (1970-76;1981 and 1994); H. B Kruger (1983); E. G Bain (1983); R.W Rowland (1983); S. B. M Marume (1983,1988 and 2015; and a few more other elegant public administration scientists; the administrative process could quite successfully be made operational in any institutional frame of reference. The frame of reference could be an international institution such as the ILO, UNESCO, IMF/World Bank; central government department, or a state university. The six main administrative categories listed by many of these scientists comprise policy, organization, finance, personnel, procedures and control (POFPPC) (Marume: 2015). According to their, line of reasoning, the concept of control is relatively comprehensive to embrace also the concept of evaluation. Therefore, the concept of control is re-defined to mean the process of:

a. Systematically monitoring (checking) activities of the public officials in implementing policy decision, programmes and plans in order to determine whether individual units and the institution itself are obtaining and utilizing their resources efficiently to accomplish their objectives, and, where this is not being achieved, taking corrective action; and

b. Eventually determining/assessing the actual practical results by a specific policy designed to accomplish some valued goals or objectives (s. B. M marume, 1988 and 2015)

For depth and analytical purposes, control measures and evaluation mechanisms are treated separately in the following paragraphs of this article.

\section{Control Measures}

Again clarity and unambiguity are needed in order to understand the concept of control measures much better.

\section{Systems Analysis}

The continuous process of reviewing system objectives, designing alternative methods to realize them, and weighing effectively costs of alternatives, mainly in an economic sense. Each alternative is regarded as full programme of subsystems - known as homeostasis. Although it is based on the principles of scientific research, systems analysis is an extension of, rather than a deviation from, human relations movement.

\section{Source: S. B. M. Marume: PhD (Public Administration) thesis, 1988}

\section{What is meant by the term 'control' in public administration?}

Marume (1988) states that in public administration at whatever governmental level, be it at international, national, provincial (state), or local, government level, it is important to recognize the fact that once the administrative functions have run their course; the practical policy results, that is, the outputs or outcomes, must be systematically evaluated in the light of the formulated and adopted policy and objectives. Specific administrative control measures are then required for use from time to time in order to ascertain whether or not the desired goal is being kept in sight. Control then is as a process of monitoring that all activities (operations) at all times and at all levels of the public institution, be it a government department, a state university, or a university faculty of commerce and law or department of education and distance learning, are carried out in compliance with the plans adopted, with the orders given, with the instructions issued, and with the principles laid down and, at the same time, assessing practical policy results.

\section{The Control Process}

According to R. N. Antony and J. Dearden (1980:19), control can be visualized as a process. Much of this process involves informal communications and interactions, by means of, amongst other things, memoranda, meetings, conversations, and even by such signals as facial expressions. Although these informal activities are of great importance, they are not easily subjected to systematic descriptions. In addition to these informal activities, there are formal controls which consist of measuring, comparing, and correcting.

But Professor S. P. Robbins (1980:377 - 384) correctly states that before considering these formal control phases, one must assume that standards exist against which measurements and comparisons may be made, and according to which corrections may be made, and according to which corrections may be brought about. Not only does planning precede and influence control, but 


\section{International Journal of Science and Research (IJSR) \\ ISSN (Online): 2319-7064}

Index Copernicus Value (2013): 6.14 | Impact Factor (2014): 5.611

effective control also provides feedback for altering inadequate standards, or measurements.

The three formal controls consisting of measurement, comparison and correction are further described as follows:

\section{a. Measuring (measurement)}

Four methods used to measure performance are:

- Personal observation;

- Statistical reports;

- Oral reports,

- Written reports.

The aim of control at any level of public institution is always to ensure that practical results of all operations conform as closely as possible to the established policies, stated goals, agreed programmes, defined objectives or targets. Three basic elements in the control process are that: (i) standards represent desired performance; (ii) a comparison exists of actual results against the set standards; and (iii) corrective action is taken in order to ensure conformity, in cases of deviation.

\section{b. Comparing (comparison)}

This is the determination of the degree of difference between actual performance and the desired performance. The comparison step in the control process requires that the measured standard is known, that the actual performance has been measured, and that guidelines exist for determining the extent of allowable tolerances.

\section{c. Correcting (correction)}

This is the third and final step in the control process and refers to the action that will correct the deviation. It entails adjusting the actual performance or correcting the standard or both. Two types of corrective action, one is immediate and deals predominantly with symptoms; and the other is basic and delves into causes.

\section{Control Criteria}

Four performance characteristics in an institution can be controlled; namely,

- Quantity: measurable outputs

- Quality: difficult to measure, for example, service to community; health care; educational service to the community.

- Cost: organizational inputs and outputs, whether human or physical, can be translated into monetary terms.

- Time: a scarce resource; deadlines.

\section{Aims of Control Measures}

Control means the systematic monitoring of all the activities at all times and at all levels of the public authority:

a) Ensuring that all operations are being carried out in accordance with the policies stated and adopted, and objectives defined, orders given and instructions issued; and

b) Methodically assessing practical policy results.

S. B. M. Marume, PhD (Public Administration) thesis, October 31, 1988

For this examination, the term control means the systematic monitoring of all the administrative activities at all times and at all levels of the public authority through two sub - processes:

a) Checking and ensuring that all operations are being carried out in accordance with the policies stated and objectives defined, orders given and instructions issued; and

b) Assessing of actual practical policy results.

\section{Typologies of Administrative Control Measures}

Administrative control in the public sector culminates in formal meetings of the political policy-making institutions, that is, conferences or legislatures which are open to the public and which from the climax of the process of public administration and in fact of the political life of the citizenry. In order to ensure that the executive authorities do in fact answer for their deeds during the sessions of the legislatures, it has become necessary in modern public administration to introduce means of detecting any wrongful actions that they might have taken. In the public sector, administrative control is make up of the two main categories, namely, internal control and control by the legislatures. In effect, according to one of the most celebrated public administration scientists, Professor J. J. N Cloete (1986:180), control in the public sector consists of two components, namely, internal control which is exercised by the executive functionaries, and external control, that is, giving account in the formal meetings of the legislatures, that is, parliaments, provincial and metropolitan councils, and local government councils)

\section{Internal Control Measures}

Internal control, which is exercised by the executive functionaries themselves, is part of the work activities of all political office- bearers and appointed public administration in charge of executive institutions in this context internal control is intended to mean

a) The Demarcation Of Work Environments, Physical Environments Or Other Environments Within Which The Public Administrators As Functionaries Have To Operate, And 


\section{International Journal of Science and Research (IJSR) \\ ISSN (Online): 2319-7064 \\ Index Copernicus Value (2013): 6.14 | Impact Factor (2014): 5.611}

b) Pointing the Way, By Means Of The Exercise Of Authority, By Example And Leadership, So That The Administrative Functions Will Individually And Collectively Pursue Their Respective Goals.

Firstly, control in any public institution, for instance, central government departments or a university is exercised to some extent by the institutional situation created by:

a) Policy-Making Body Which Defines The Field Of Work And Sets Out The Objectives To Be Achieved;

b) The Organizational Arrangements Which Give Form To The Institutions Responsible For The Field Of Work And Which Also Determine The Relations Which Each Functionary Bears To The Others. Hence There Will Be A Determination Of Specific Positions In An Hierarchical Structure; The Role Of Each Position; A Division of Labour; Definition Of Lines Of Authority; Structural Arrangements For Delegation Of Authority, And Reporting System;

c) The Determination And Where Necessary Recording of The Work Procedures Which The Functionaries Have To Follow; and

d) The Financing Arrangements.

Secondly, the control is exercised in the institutional situation by the use of formal control measures which ensure that everything which the functionaries do is in fact aimed at achieving the set objectives. Examples of aids for formal internal control measures are budget, reports, inspections and investigations, auditing, procedural arrangements, and organizational arrangements, and instructions setting out clearly the minimum standard and volume of work expected of the functionaries as they provide services to the communities, as well as the work programmes which have to be adhered to.

Thirdly, internal control is exercised in an informal manner by the influence which functionaries exercise over each other. Of special significance in this regard is the continuing supervision which supervisors exercise over their juniors, the examples they set for them and the administrative leadership they give them.

Closer attention is given to the formal and informal internal control measures as shown:

\section{The budget}

The budget is a carefully designed programme of the work which the executive institutions intend to undertake. Parliament approves, conducted on the basis of the budget which is a comprehensive financial statement which specifies the purposes for which the money is required.

\section{Auditing}

Auditing is one of the traditional administrative control measures which are always useful. The auditing is done after the transactions have taken place in order to determine the legal correctness of all financial transactions, and to check whether the monies have been widely used and for the intended purposes.

\section{Inspections and investigations}

Inspections and investigations in loco by a single functionary or a group is also a well-known traditional administrative control measure in the normal public sector. Internal and external auditors at times make separate inspections and investigations on the financial performance of the executive institution (government department) and prepares and submit reports on their observations to the Secretary of the Ministry of Finance and the Comptroller and Auditor- General.

\section{Procedural arrangements}

Fixed work methods and procedures which determine the manner and speed with which service is rendered should be laid down work procedures for the executive institutions, are laid down in procedural codes dealing with aspects such as records keeping, mail handling, personnel issues and financial matters. As already shown all these are internal procedural measures which are designed to facilitate the work operations of the executive institution.

The political policy directives/ laws/ declarations are implemented only by executive institutions which are constituted in any orderly manner. The executive institutions are arranged in such a manner that some form of an hierarchal structure of officers and officials is obtained. The one officer reports to the other in the same way that subordinate officials have to give account to their superiors.

\section{External Control Measures}

\section{Political control of administration}

In this article: "The study of Administration", Woodrow Wilson (1887) remarked that: "It is getting to be harder to run a constitution than to frame one", implying that when legislation has been enacted, it did not automatically follow that execution would necessarily be in terms of the legislator's intention. S. X. Hanekom and C. Thornhill (1983: 176) state that from this remark could also be deducted that the framers of a constitution, (including the legislator) should, when passing an act, provide measures to guarantee that the executive attain the objectives set by the legislature. They write: "The political representatives constituting the legislative body should therefore make provision for control, and exercise final control over executive actions".

The identification of an objective does not imply that it will be attained. The following may be cited as reasons why objectives are not attained (Hanekom and Thornhill, 1983: $180-181)$ :

- Imperfect knowledge as to the factors that can affect the attainment of the objectives concerned; 


\section{International Journal of Science and Research (IJSR) \\ ISSN (Online): 2319-7064}

Index Copernicus Value (2013): 6.14 | Impact Factor (2014): 5.611

- Inadequate resources could prevent the executive from achieving objectives;

- Organizational deficiencies could hamper the effective execution of government programmes;

- Leadership problems could prevent institutions from predicting future needs and making provision for meeting these needs;

- Dependence on other executive institutions could hamper an institution; and

- Communication failures and delays within the executive.

According to Hanekom and Thornhill (1983: 183 - 184), there are limitations to political control of administration, and factors such as the following may inhibit the proper utilization of control measures:

- Excessive emphasis on secrecy;

- Lack of analytical capabilities;

- Invalid control measures;

- Political bias;

- Divergent perceptions; and

- Superficialities: the legislative tends not to investigate executive actions meticulously, but to review public activities superficially.

In western public administration public accountability is a characteristic control measure.

Although the legislature is the final controlling body in a democracy, it does not itself make detailed investigations of all executive actions. It has, however, developed measures to assist it in performing its controlling action effectively. Some of these measures are as follows:

1) The accounting officer, departmental secretary

2) A state treasury

3) Public service commission

4) Government auditor

5) Ministers of state

6) State budget

7) Parliamentary select committees

8) Annual reports

9) An ombudsman

Thus, one of the philosophical foundations of public administration at any governmental level is that the legislature, for instance, parliament, provincial council, and town council which are all political institutions, has control over the sphere of work of the public officials.

\section{Control over policy}

Parliament and cabinet give the general direction to the executive institutions operations. The political directions of the respective cabinet ministry with the permanent secretary as the administrative head.

\section{Establishment of executive institutions}

Parliament views institutions as facilitating and consequential rather than as causative forces or ends in themselves. Government seeks to develop concrete areas of activity and to identify their actual servicing requirements first and only then to create institutional structures. Therefore, it has started with a minimum of bureaucratic machinery, thus both allowing for and requiring close governmental consultation. The overriding objective is to ensure coherent and concrete implementation of decisions.

\section{Control over personnel arrangements}

In terms of the secretariat: position descriptions, appointment conditions, terms and conditions of employment, and any other relevant national civil service commission terms of conditions of service mutually agreed upon, the SADCC Council of Ministers has power to lay down conditions on how personnel are appointed, remunerated, promoted and dismissed.

\section{Control over auditing}

The general rule applies that the executive institutions can incur expenditure over the activities of the approved programme of action. The parliament of Ministers bears the final responsibility for the manner in which public funds are spent. At the same time, both the executive utilization as the recipient governments have auditors who ensure that the monies have been used to the best of advantage in all government departments.

Next we examine evaluation methodology.

\section{Evaluation methodology}

In examining the importance of the concept of evaluation, this is what Hene Nagel Bernstein and Eleanor Bernert Sheldon quoted by $\boldsymbol{R}$. B. Smith (1983:93) say:

There is no necessity for working social scientists to allow the political meaning of their work to be shaped by the accidents of its setting, or its use to be determined by the purposes of other men. It is quite within their powers to discuss its meanings and decide upon its uses as matters of their own policy.

\section{Source: C. Wright Mills: The sociological imagination:} New York, 1959.

Evaluative research deserves full recognition as a social science activity which will continue to expand. It provided excellent and ready - made opportunities to examine individuals, groups, and societies in the grip of major and minor forces for change. Its applications contribute not only to a science of social planning and a more rationally planned and psychological theories of change (Charles $\boldsymbol{R}$. Wright: Evaluation research, in international encyclopedia of the social sciences: New York: Free Press, 1968, p. 202).

The 1970s, a decade of rapid - paced social change, was marked by the proliferation of large - scale social action programmes, planned social interventions designed to ameliorate or solve existing social problems. In society today, particularly in the United States, huge expenditures of time, personnel, and funds are allocated to persons and organisations attempting to find solutions to problems both local, state and national. 


\section{International Journal of Science and Research (IJSR) \\ ISSN (Online): 2319-7064 \\ Index Copernicus Value (2013): 6.14 | Impact Factor (2014): 5.611}

Perhaps nothing is more important to the success of social action programmes than that we know whether or not they work and what effect they have. It almost goes without saying or should that in order to modify or terminate programmes rationally, intelligently, and sensibly that are not achieving their objectives, and to continue and expand those that are, some evidence is needed of their efficiency and effectiveness.

In recent years interest has mounted for employing the research techniques of social science in efforts to determine the effectiveness of social action programmes and the means by which best to allocate economic and personnel resources to the. This interest has resulted in a demand for evaluative research, defined as the use of the scientific method for the purpose of judging the worth of some activity.

\section{Definition of Evaluation}

In addition to looking at evaluation research from the viewpoint of its rationale and focus, that is, as a policy perspective, the analytical or measurement perspective may be addressed. The many typologies of evaluation tend to resolve themselves into impact, relative effectiveness, and project performance. The methods used to measure programme outcomes, depend partly on the type of evaluation intended and partly on the available time, resources and expertise.

- Impact evaluation seeks to measure the extent to which a programme has met its legislative objectives.

- Relative effectiveness evaluation addresses the range of programme strategies, techniques, and processes available for accomplishing the legislative objectives.

- Programme evaluation measures the performance of project operations.

\section{Evaluation}

According to Professor Robert B. Smith (1983:94), evaluation means different things to different people. Terms like assessment, appraisal, and judgment are often used synonymously for evaluation. As a result there is no clear - cut understanding of the basic requirements of evaluation research. Generally speaking, the term covers a wide range - from examination of intake records, surveys, testimonials, anecdotal material, and so on - all the way through the complex experimental designs.

It includes highly subjective impressions as well as detailed mathematical and statistical analyses.

\section{Distinction between evaluation and evaluative research}

Professor Edward Suchman (1967) makes a distinction between evaluation and evaluative research, which we have followed in this discourse. He does this in an attempt to distinguish between.

a) Evaluation as a process of judging the worthwhileness of some activity, regardless of the method employed and

Volume 5 Issue 1, January 2016 b) Evaluative research as the specific use of the scientific method for the purpose of making an evaluation. Thus he separates evaluation as a goal from evaluative research as a particular means of obtaining that goal.

\section{Evaluation as a Process}

Professor Edward Suchman (1967: 31 - 32) writes that the rage of variation of the meaning of evaluation can be indicated by clearly defining evaluation as the determination (whether based on opinions, records, subjective or objective data) of the results (whether desirable or undesirable, pleasant or unpleasant; transient or permanent; immediate or delayed) attained by some activity (whether programme, or part of a programme, a drug or a therapy, an ongoing or one shot approach) designed to accomplish some valued goal or objective (whether ultimate, inter mediate, or immediate, effort or performance, long or short range).

Simply stated, evaluation is the determination of results attained by some activity designed to accomplish some goal or objective (Marume, 1988).

This definition of evaluation contains four key dimensions:

$\begin{array}{lll}\text { 1. Process } & - & \text { The Determination } \\ \text { 2. Criteria } & - & \text { The Results } \\ \text { 3. Stimulus } & - & \text { The Activity; and } \\ \text { 4. Value } & - & \text { The Objective }\end{array}$

Other scientists, like Erwin Schwella, William Fox and Henry Wissink, view the concept of evaluation as follows:

Evaluation assesses: actual practical results produced by a specific public policy, or proposed programme.

A typical evaluation, which aims at improving policy itself and programme decisions, proceeds through five stages, namely, a determining fairly accurately the decision maker's needs;

- Designing;

- Implementing;

- Reporting, And

- Dissemination

\section{Evaluation Research}

It is important to note that evaluation research and public policy analysis often resemble each other as elaborate below:

Evaluation research also about

- The kind of change that is desired;

- The means by which this change is to be brought about;

- The criteria according to which such change can be recognized; and

- The related results and effects. 


\section{International Journal of Science and Research (IJSR) \\ ISSN (Online): 2319-7064}

Index Copernicus Value (2013): 6.14 | Impact Factor (2014): 5.611

Evaluation research as a methodology assesses

- Actual practical results produced by a specific policy;

- Possible/probable economy, costs and benefits of the various public policy alternatives available.

\section{Internal evaluation research techniques}

Evaluation research, programme evaluation, productivity improvement is an approach, to the control of administration. The primary aim of evaluation is to:

i. Asses the actual practical results produced by a specific public policy, and

ii. What possible/probable economy, costs and perceivable benefits of public policy alternative available could

\section{Evaluation Methods}

General means (methods) that have been used to evaluate programmes have been

- Monitoring;

- Financial management auditing;

- Investigatory journalism; and

- Public debating.

\section{Evaluation Process}

The evaluation process consists of

- Defining Decision Makers’ Needs;

- Designing And Structuring;

- Implementing;

- Reporting; And

- Dissemination

\section{Evaluation Purposes}

Evaluation research is commissioned for purposes of:

- Compliance;

- Process improvement;

- Theory testing; and

- Knowledge - building

\section{Evaluative Research}

The scientific method with its accompanying research techniques then provides the most promising means for determining the relationship of the stimulus to the objective in terms of measurable criteria.

\section{Critical comment on Edward Suchman's conceptual distinction}

Professor Edward Suchman's conceptual distinction between evaluation as a process and evaluative research as the specific use of the scientific method does not rule out the use of nonscientific methods for evaluation. $\mathrm{He}$ mentions that many evaluation questions in programme planning, development, and actual operation can be addressed and answered without research and that many others cannot be answered even with the best techniques. He cautions that evaluators must be aware of which tool or technique they are using and careful not to substitute a subjective appraisal for an evaluation requiring a scientific research approach.

\section{Methodological viewpoint of evaluation}

From a methodological point of view, the key elements of evaluation are as follows:

5.3.1 Specification of a planned programme of deliberate intervention;

5.3.2 Statement of an objective or goal that is considered desirable or has some positive value;

5.3.3 A method for determining the degree to which the planned programme has been implemented and has achieved its objectives; and

5.3.4 An assessment of any unanticipated consequences of the planned intervention.

\section{Evaluation Research}

Evaluation research asks about the kind of change that is desired, the means by which this change is to be brought about, the criteria according to which such change can be recognized, and related results and effects. Obviously the emphasis is an social change, conceiving of evaluation studies as studies of social change is underscored by Professors Herbert Hyman and Charles Wright (1967: 741) in their definition of evaluative research as the procedures of fact finding about the results of panned social action.

\section{Evaluation process}

The evaluation process itself can be diagrammed as in Figure 1 below: 
International Journal of Science and Research (IJSR)

ISSN (Online): 2319-7064

Index Copernicus Value (2013): 6.14 | Impact Factor (2014): 5.611

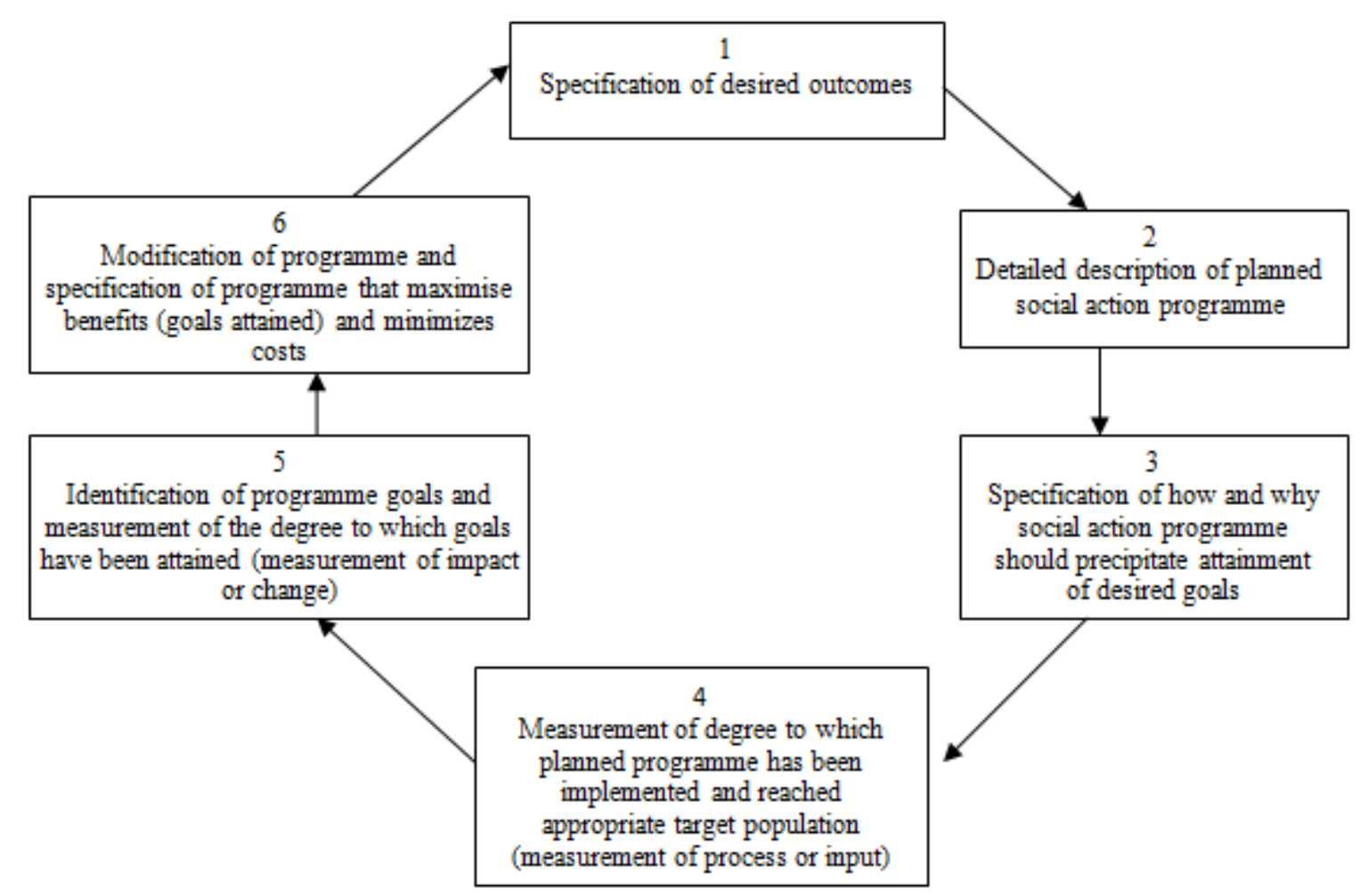

Figure 1: The Evaluation Process

\section{Commencement of Evaluation Process}

The evaluation process commences with examination of a set desired outcomes, such as income redistribution, adequate housing for the poor, or community mental health. A programme of planned intervention is then proposed wherein implementation of certain activities is expected to of providing adequate housing for the poor. In good evaluation studies the evaluator makes certain that the urban renewal plan is specified in sufficient detail so that all of the components of the programme plan are clearly explicated. Detailed specification of the programme and any modification also serve as a set of criteria against which the degree of implementation can be measured.

Moreover, should the programme prove to be effective in producing the desired outcomes, a detailed account of what the programme entailed is available for others to copy or modify. Once the programme components have been specified;

- The next step is to provide a rationale for the expectation that implementation of the programme will produce the desired outcomes; and such a rationale may be conceived of as the theoretical underpinning of the evaluation;

- Next, it is important to measure the degree to which the program has been implemented and whether it has reached the target population;

- After measuring programme process, the evaluator should proceed to identify the specific goals of the programme as defined by the programme administrators, program participants and to specify the way in which changes on these goals will be measured;
- This done, the next step is to implement a research design that provides maximum validity of findings in terms of the measurement of programme impact.

\section{End of evaluation process}

Finally, the evaluator should interpret all of the findings and recommend a next step in the reform experiment process that brings attainment of the desired outcomes closer. Given the new plan or programme, the evaluation process begins all over again.

\section{Evaluation Cycle and Recommences}

Theoretically, the evaluation cycle stops only when the desired outcomes have been attained at the desired level. In this way according to Lee J. Cronback (1980:2), evaluation is also the handmaiden to gradualism - both conservative and committed to change.

\section{Summary on Control Measures and Evaluation Mechanisms}

\section{Control Measures}

Control is the process of monitoring activities to determine whether individual units and the institution itself are obtaining and utilizing their resources effectively and efficiently in order to attain their objectives, and where this is not being achieved, implementing corrective actions.

Four common sources of performance measurement are: personal observation, statistical reports, oral reports, and written reports. 


\section{International Journal of Science and Research (IJSR) \\ ISSN (Online): 2319-7064}

Index Copernicus Value (2013): 6.14 | Impact Factor (2014): 5.611

Four criteria by which performance can be controlled are: quantity, quality, economy and cost, and time.

Public objectives may not be attained because of imperfect knowledge, inadequate resources, organizational deficiencies, leadership problems, dependence on other executive institutions and communication failures.

Some political controls are exercised by the legislature through the accounting officer, a state treasury, public service commission, a state auditor, ministers of state, state budgets, parliamentary select committees, annual reports, and ombudsman.

\section{Evaluation Mechanisms}

The aim of evaluation is to evaluate the results produced by a policy, and what the costs and benefits of alternatives would be.

Programmes are scrutinized through monitoring, financial auditing investigatory journalism and public debating.

The evaluation process consists of defining decision makers' needs, designing and structuring, implementing, reporting and dissemination.

The measures to evaluate programme outcomes are: impact evaluation, relative effectiveness evaluation, and project performance.

\section{Conclusion on Control Systems and Evaluation Mechanisms}

In the government department, two types of control, namely, internal control and control by the political (legislative) bodies have been identified. These two types of control manifest themselves in the administration of government department In exercising the internal control function, several aids are made use of, for instance, the budget, auditing, inspections and investigations, procedural arrangements and organizational arrangements.

\section{References}

[1] J. J. N Cloete: Introduction to Public Administration: J. L Schaik: Pretoria: 1986.

[2] J. N Cloete: Provincial and Municipal Government and Administration: selected readings.

[3] J. J. N Cloete: South African Public Administration: selected readings J. L. Van Schaik: Pretoria: 1977.

[4] F. M. Marx (ed): Elements of Public Administration Prentice - Hall, Englewood Cliffs, 1959.

[5] H. A Simon, D. W Smithburg and V. A Thompson: Public Administration: Alfred A. Knoff, New York, 1971.

[6] E. N. Gladden: The Essentials of Public Administration: Stapples Press Limited: London, 1964.
[7] J. D. Millet: Organization for the Public Service: Dornas van Nostrand Company, Inc, Princeton, New Jersey, 1966.

[8] E. L Normanton: The accountability and Audit of Governments: A comparative Study: Manchester University Press: Manchester, 1966.

[9] H. Britain: The British Budgetary System:_George Allen and Univen Limited: London, 1959.

[10]O. G Stahl: Public Personnel Administration: $5^{\text {th }}$ edition: Harper and Row, Publishers: New York, 1962.

[11]S. P. Robbins: The Administrative Process: Englewood Cliffs: New Jersey, Prentice- hall, 1980.

[12]J. C. Charlesworth (ed): Theory and Practice of Public Administration: Scope, Objectives, and Methods. Philadelphia: the American Academy of Political and Social Science, 1968.

[13]S. X. Hanekom and C. Thornhill, Public Administration in Contemporary Society. Johannesburg: MacMillan, 1983.

[14] J. E. Anderson, Public Policy Making: New York Holt, Rinehart and Winston, 1979.

[15] S. X. Hanekom, R.W. Rowland and E.G Bain: Key Aspects of Public Administration First edition; Southern Book Publishers: Southern Africa, 1987.

[16] S. P. Robbins: The Administrative process: Prentice Hall, New Jersey, 1980.

[17] Herbert Hyman and Charles Wright: Evaluating Social action programmes: New York, 1967.

[18]Edward Suchman: Evaluative research New York, 1967.

[19] S. B. M. Marume: Public Administration: special contemporary problems and challenges; LAP Lambert Academic Publishing, Berlin, Germany, 2015 [ISBN 978-3-659-75883-6]

[20] S. B. M. Marume: Normative factors in public administration: LAP Lambert Academic Publishing: Berlin, Germany 2015 [ISBN 978-3-659-49921-0].

[21] S. B. M. Marume: International politics: Africa on sub - regional systems basis: LAP Lambert Academic Publishing, Berlin Germany, 2015 [ISBN $978-3-659-80183-9]$

\section{Author Profile}

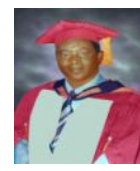

Samson Brown Muchineripi Marume: born on 15 July 1943; a former senior civil servant for 37 years and deputy permanent secretary; ten years as a large commercial former; well travelled domestically, regionally [SADC countries and Africa's Kenya, Ethiopia, Sudan, Libya, Uganda]; and internationally [Washington, New York and California in USA; Dublin and Cork in Ireland; Netherlands, France, former Yugoslavia Belgrade; Rome and Turin in Italy; Cyprus - Nicosia; Athens - Greece; Beijing - China; Singapore; Hong Kong; Japan; and UK]; six years as management consultant and part - time lecturer and $\mathrm{PhD} / \mathrm{DPhil}$ thesis supervisor, internal and external examiner; researcher and writer and currently senior lecturer and acting chairperson of Department of Public Administration in Faculty of Commerce and Law of Zimbabwe Open University; is a graduate BA, special Hons BA, MA [Public Administration] [Unisa, South 


\section{International Journal of Science and Research (IJSR) \\ ISSN (Online): 2319-7064}

Index Copernicus Value (2013): 6.14 | Impact Factor (2014): 5.611

Africa], MAdmin magna cum laude in transport economics, MSoc Sc cum laude in international politics, $\mathrm{PhD}$ summa cum laude in public administration [CUAS, California, United States of America].

Roy Robson Jubenkanda: 2008, DPhil (Currently pursuing DPhil pursuing DPhil studies with (ZOU); 2000, MSc in Strategic Management - University of Derby, U. K; MSc. Econ. In international Economics, Banking and Finance- University of Wales, Cardiff College of Business Studies, U.K.; 1983, BSc (Hons) Degree in Economics University of Zimbabwe, Zimbabwe; 1976 Business Studies Diploma - Solusi University, Zimbabwe; 2005, Certificate in Distance Education Practitioner (UNISA); 2011, Certificate in Higher Education Management in Southern Africa (University of the Witwatersrand) Johannesburg, South Africa.

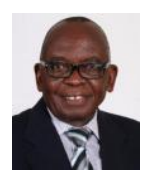

Cornelius Wonder Namusi: current studies: DPhil (candidate) in Public Administration; 1991, Master of Public Administration (UZ); 1982, Bachelor of Administration Honours (UZ); 2011, Certificate: Module Writing; 2011, Certificate: Managing the training programme ESAMI, Tanzania; 1990, Certificate advanced work study (Canada); 1986, Certificate: Organisation and methods O \& M), Institute of Development Administration IDM Botswana); 1983, Certificate in Labour Administration, African Regional Labour Administration Centre (ARLAC) (Nairobi); 1964, Primary Teachers Higher Certificate (PHT) Waddilove Teacher Training Institution, Marondera, Zimbabwe. 